\title{
Peranan Public Relation Dalam Memasarkan Produk Motor Yamaha ke Masyarakat
}

\author{
Mochamad Faisal Ardiansyah', Fahri Ihsanudin'2, Danistiar Arif Putra ${ }^{3}$, Pani Audria ${ }^{4}$
}

Program Studi IImu Komunikasi, Fakultas IImu Komunikasi, Universitas Islam Nusantara Bandung

\begin{tabular}{|c|c|}
\hline ARTICLE INFO & ABSTRACT \\
\hline Article history: & \multirow{4}{*}{$\begin{array}{l}\text { Humans are social creatures who live and must always socialize } \\
\text { with other humans around them. Therefore, humans must have the } \\
\text { courage to speak or what is commonly called public speaking. It } \\
\text { humans have the courage to speak up, then humans can run public } \\
\text { relations in a company. In this scientific paper of our group, we use } \\
\text { descriptive quantitative research methods. Descriptive quantitative } \\
\text { is a method in researching the status of human groups, an object, a } \\
\text { condition, a system of thought or a class of events in the present } \\
\text { mass, the aim is to make a descriptive, picture or painting about } \\
\text { public relations in marketing products to the public. In the research } \\
\text { that we did by collecting interview data, we found out how the } \\
\text { strategies were created by several public relations actors. On } \\
\text { average, these actors use online marketing strategies and also } \\
\text { some do marketing by including brochures about products that are } \\
\text { marketed to the company or the nearest office by providing } \\
\text { discounts or attractive prices. }\end{array}$} \\
\hline $\begin{array}{r}\text { Received Oct 02, } 2021 \\
\text { Revised Nov 09, } 2021 \\
\text { Accepted Nov 20, } 2021\end{array}$ & \\
\hline Keywords: & \\
\hline $\begin{array}{r}\text { Human; } \\
\text { Public Relations; } \\
\text { Strategi. }\end{array}$ & \\
\hline
\end{tabular}

\begin{abstract}
ABSTRAK
Manusia adalah makhluk sosial yang hidup harus senantiasa bersosialisasi dengan manusia lain disekitarnya. Maka dari itu manusia harus memiliki keberanian untuk bersuara atau yang biasa disebut dengan public speaking. Jika manusia memiliki keberanian untuk bersuara, maka manusia bisa menjalankan public relations dalam suatu perusahaan. Dalam karya tulis ilmiah kelompok kami ini, kami menggunakan metode penelitian kuantitatif deskriptif. kuantitatif deskriptif adalah suatu metode dalam meneliti status kelompok manusia, suatu objek, suatu kondisi, suatu sistem pemikiran ataupun suatu kelas peristiwa pada massa sekarang, tujuanya adalah untuk membuat deskriptif, gambaran atau lukisan mengenai public relation dalam memasarkan produk ke masyarakat. Dalam penetian yang kami lakukan dengan pengumpulan data wawancara menghasilkan bagaimana cara strategi yang diciptakan beberapa pelaku public relations. Rata rata pelaku tersebut, menggunakan strategi pemasaran dengan cara online dan juga sebagian melakukan pemasaran dengan memasukan brosur-brosur tentang produk yang dipasarkan kepada perusahaan atatu kantor terdekata dengan memberikan diskon atau juga harga yang menarik.
\end{abstract}

This is an open access article under the CC BY-NC license.

\section{Corresponding Author:}

Mochamad Faisal Ardiansyah

Program Studi Ilmu Komunikasi, Fakultas Ilmu Komunikasi, ,

Universitas Islam Nusantara Bandung,

Jl. Soekarno-Hatta No.530, Sekejati, Kota Bandung, Jawa Barat 40286

Email : faisalardiansyah980@gmail.com 


\section{PENDAHULUAN}

Manusia adalah makhluk sosial yang hidup secara berkelompok dan saling membutuhkan satu sama lain. Komunikasi dapat mempermudah manusia dalam melakukan interaksi, sehingga maksud atau tujuan dapat terwujud. Manusia sebagai makhluk sosial tentu ingin memenuhi kebutuhan secara umum baik ekonomi maupun biologis untuk memenuhi kebutuhan itu maka dari itu manusia tidak dapat berdiri sendiri ia harus berinteraksi satu sama lain. Komunikasi adalah suatu transaksi, proses simbolik yang menghendaki orang-orang mengatur lingkungannya dengan membangun hubungan antara sesama manusia melalui pertukaran informasi untuk menguatkan sikap dan tingkah laku orang lain serta berusaha mengubah sikap dan tingkah laku. (Hafied Cangara,2011)

Definisi public relation sebagai fungsi manajemen dari ciri yang berkelanjutan melalui organisasi dan lembaga swasta atau public (umum) untuk memperoleh pengertian, simpati dan dukungan dari mereka yang terkait atau mungkin ada sebelas hubungannya dengan penelitian opini publik diantara mereka (Ishak, 2012). Public Relation melakukan komunikasi dengan beberapa kelompok masyarakat dengan tujuan menciptakan lingkungan yang lebih kondusif, kemudahan untuk melakukan aktivitas pemasaran dan kegiatan lain dari perusahaan. Public relations merupakan kelanjutan dari proses pendapatan kebijaksanaan, penentuan pelayanan dan sikap yang disesuaikan dengan kepentingan orang-orang atau golongan agar orang atau lembaga itu memperoleh kepercayaan dan good will dari mereka.

Perusahaan adalah salah satu bisnis yang keberadaannya bisa terancam jika para pemilik kepentingan ini tidak memiliki citra yang positif terhadap perusahaan dan merek produk serta kegiatan yang dikerjakan perusahaan. Citra adalah suatu gambaran tentang imajinasi atau ide yang dihasilkan oleh kepribadian yang ditunjukan kepada publik oleh seseorang, organisasi dan sebagainnya. Perusahaan yang memiliki citra baik dimata konsumen, produk dan jasanya lebih bisa diterima konsumen dari pada perusahaan yang tidak mempunyai citra. Perusahaan yang memiliki citra positif dimata konsumen juga cenderung bertahan pada masa masa yang sulit. (Dharnayanti, 2017)

Fungsi utama humas adalah untuk mencapai tujuan dan menciptakan cira yang positif bagi perusahaannya (Image Maker), selain memelihara hubungan baik dengan seluruh publik baik public internal maupun public eksternal. Dengan demikian citra merupakan salah satu aset yang paling penting dari perusahaan atau organisasi yang harus terus menerus dibangun dan dipelihara. Citra perusahaan tidak bisa direkayasa, artinya citra tidak datang dengan sendirinya melainkan dibentuk. Fungsi public relations di suatu perusahaan jika dilaksanakan dengan baik akan menjadi alat yang sangat ampuh guna memperbaiki sistem di perusahaan dan mengembangkan peraturan, budaya perusahaan atau organisasi, suasana kerja atau internal perusahan yang lebih kondusif, dan peka terhadap karyawan yang memang perlu pendekatan khusus guna memotivasi dan meningkatkan kinerjanya. (Nasution, 2019)

Salah satu tujuan Eksternal Public Relations adalah untuk mengeratkan hubungan dengan orang-orang diluar instansi hingga terbentuklah opini publik yang favorable terhadap badan itu dan juga bagi suatu perusahaan hubungan-hubungan dengan publik diluar perusahaan itu merupakan suatu keharusan di dalam usaha-usaha untuk Memperbaiki hubungan dengan serikat-serikat buruh, mencegah pemogokan-pemogokan dan mempertahankan karyawan-karyawan yang cakap, efektif dan produktif dalam kerjanya. Tugas yang diembankan pada public relation dibutuhkan kreatifitas yang tinggi sehingga seorang public relation dapat membuat strategi dalam penjulan jasa/produk terhadap konsumen (eksternal) serta terus melakukan inovasi guna mempertahankan citra yang baik terhadap lembaga atau orgamnisasi ditengah-tengah masyatrakat. (Artis, 2011)

Lalu mengapa perusahaan membutuhkan peran public relation di perusahaan nya? Karena pemasaran adalah bentuk terpenting dalam proses perencanaan yang muncul dari pengenalan pasar dan apakah yang dapat ditawarkan kepada pasar. Banyak perusahaan yang memanfaatkan dan menggunakan jasa atau peran public relations pemasaran dalam meningkatkan kesadaran masyarakat terhadap produk baru maupun produk yang sudah terkenal. Komunikasi adalah usaha yang dilakukan untuk memberikan informasi membujuk, mengingatkan atau menyampaikan kepada publik mengenai keberadaan produk maupun jasa yang dijual agar bisa beredar dan di terima di pasar. (Muchlisin Riadi, 2018) 
Studi pendahuluan merupakan tahap awal dalam melakukan penelitian dan pengembangan model. Pada penelitian ini, peneliti melakukan wawancara kepada seorang public relation yaitu 5 orang pegawai dalam perusahaan motor Yamaha dan 5 orang konsumen pada perusahaan tersebut. Untuk seorang public relation, agar bisa memasarkan sebuah produk harus memiliki public speaking yang bisa dikatakan bagus, untuk meyakinkan konsumen. Public Speaking dikatakan menjadi pegangan penting karena dengan menjelaskan seluruh kelebihan produk, salah satu contohnya yaitu produk motor dari Yamaha. Jika penawaran yang dilakukan bagus maka akan membuat konsumen tertarik untuk membelinya.

Dalam perusahaan public relation bisa dikatakan sangat penting. Karena penyampai dari karyawan terhadap atasnya. Menyampaikan kinerja karyawan baik yang bekerja dengan bagus maupun yang bagus. Public Relations sebuah organisasi tidak semata-mata menjadi tanggungjawab praktisi Public Relations tetapi harus menjadi tanggungjawab para pengelola organisasi tersebut. Menjadi public relations bukan hal yang mudah, melainkan menjadi tanggung jawab yang sangat penting dalam suatu perusahaan. Public Relations sebagai fungsi manajemen berkaitan dengan bagaimana sebuah organisasi menyusun kebijakan sehingga memperlihatkan sebuah kinerja yang bertanggungjawab. (Amie Primarni, 2015)

Aktifitas Public Relations meliputi kegiatan mulai dari pembenahan organisasi itu sendiri, hingga kegiatan yang bersifat membangun atau menciptakan citra perusahaan dan hubungan yang positif dimata publiknya. Bidang public relations merupakan bidang yang sangat luas dan menyangkut hubungan dengan berbagai pihak. Lebih dari itu, public relations mengandalkan strategi, yakni agar organisasi disukai oleh pihak-pihak yang berhubungan. Fungsi utama Humas adalah untuk mencapai tujuan dan menciptakan citra yang positif bagi perusahaannya (image maker), selain memelihara hubungan baik dengan seluruh publik baik publik internal maupun publik eksternal. (Isna Asdiani Nasution, 2019).

\section{METODE PENELITIAN}

Jenis penelitian yang digunakan adalah penelitian kuantitatif deskriptif. Berdasarkan Widoyoko (2016), kuantitatif deskriptif adalah suatu metode dalam meneliti status kelompok manusia, suatu objek, suatu kondisi, suatu sistem pemikiran ataupun suatu kelas peristiwa pada massa sekarang, tujuanya adalah untuk membuat deskriptif, gambaran atau lukisan mengenai public relation dalam memasarkan produk ke masyarakat Sebagaimana adanya Data Terkumpul. Penelitian dilakukan dengan terlebih dahulu mengadakan survei kepada Pegawai dan Konsumen Perusahan Motor yamaha mengenai Bagaimana cara pemasaran produk dan kepuasaan konsumen. Untuk mengetahui mengenai public relation maka di lakukan wawancara dengan mengajukan 10 pertanyaan terkait public relation. Kemudian memberikan suatu kuisioner berupa angket terkait penilaian mengenai produk atau publik realtion dengan jawaban berupa YA atau TIDAK.

Untuk memperoleh data yang berkaitan dengan penelitian ini, peneliti melakukan pengumpulan data. Adapun sumber data yang diperoleh terdiri dari: Angket/ kuesioner yaitu sejumlah pertanyaan tertulis yang digunakan untuk memperoleh informasi dari responden dalam arti laporan tentang pribadinya, atau hal-hal yang ia ketahui. 1) Kuesioner yang penulis sajikan akan diberikan kepada pegawai perusahan motor yamaha dan Konsumennya. Sebanyak 10 Responden di bagi merata 5 orang pegawai dan 5 orang konsumen. 2) Kajian Pustaka yaitu data diperoleh melalui kajian beberapa literatur yang berkaitan dengan permasalahan yang dibahas, dari rujukan teoritis yang relevan dengan membaca Jurnal yang berkaitan dengan public speaking atau Humas (Sudijono, 2011). 3) Wawancara yaitu pengumpulan data yang dilakukan dengan mengadakan tanya jawab langsung kepada pihak-pihak yang terkait untuk melengkapi data-data analisis

\section{HASIL DAN PEMBAHASAN}

Informan 1 (DD) menjawab: media online, seprerti facebook dan instagram yang sebelumnya disebutkan menjadi salah satu keefektifan dalam menjalankan strategi yang kami jalankan, dari pertanyaan media apa yang anda gunakan dalam memasarkan produk?

Informan 2 (AH) menjawab: media yang digunakan dalam memasarkan produk, menggunakan media sosial atau media online, dari pertanyaan "Media apa yang digunakan dalam memasarkan produk?" 
Informan 3 (MW) menjawab: "Media yang digunakan untuk memasarkan produk adalah menggunakan media cetak dan media online", dari pertanyaan "Media apa yang digunakan dalam memasrkan produk?"

Berdasarkan Purbohastuti (2017:230) promosi menggunakan media sosial lebih mudah diakses dimana saja dan kapan saja, setiap hari handphone dibawa kemana-mana dan selalu up date. Dapat promosi tidak berbayar dan lebih luas untuk market sharenya. Jadi promosi melalui media sosial itu sangat efektif.

Informan 1 (DD) menjawab: strategi yang yang lebih kuat untuk masa pandemi ini yaitu dengan menyebarluaskan iklan-iklan di facebook dan instagram dengan cara rutin agar konsumen tertarik dari pertanyaan strategi apa yang digunakan untuk memasarkan produk?

Informan $2(\mathrm{AH})$ menjawab: "Strategi yang kami gunakan adalah memasarkan dengan mengiklankan di media sosial, seperti Instagram dan facebook, karena media sosial terutama instagram merupakan suatu asset penting dalam memasarkan produk secara online, selain dari itu instagram juga memiliki salah satu media terbesar yang ada saat ini", dari pertanyaan "Strategi apa yang digunakan dalam memasarkan produk?".

Informan 3 (MW) menjawab: "Strategi dengan memberikan brosur-brosur dan juga pemasaran online menggunakan media sosial Instagram", dari pertanyaan "Sstrategi bagaimana yang digunakan dalam meamasarkan produk?".

Menurut Untari dan Dewi (2018:273) Social media marketing adalah strategi kegiatan pemasaran menggunakan situs-situs media sosial seperti Facebook, Twitter, Instagram, Youtube, dan sebagainya. Media sosial merupakan salah satu cara yang ampuh untuk mempromosikan produk barang dan jasa yang kita miliki melalui internet marketing. Caranya mudah sederhana tetapi memiliki efek yang luar biasa.

Informan 1 (DD) menjawab: memposting iklan diskon dan banyak promo lainya membuat konsumen dapat tertarik dan segera bertanya tanya tentang produk motor yang dipasarkan dari pertanyaan bagaimana cara anda memasarkan produk anda agar terlihat lebih menarik di banding produk yang lain? Rahayu (2019:50) menyatakan penawaran diskon yang menarik menjadi daya tarik tersendiri. Bersamaan hal tersebut, diskon menjadi daya tarik konsumen untuk membeli produk motor tersebut. Indikator harga murah dan jumlah pembelian motor pada variabel diskon memberi dampak positif pada minat beli konsumen dengan indikator membeli motor.

Informan 1 (DD) menjawab: orang-orang yang berlalu lintas dijalan juga karyawankaryawan kantor, seperti karyawan hotel dan sejenisnya dari pertanyaan apa objek utama perusahaan ini dalam memasarkan produk motor tersebut?

Informan 2 (AH) menjawab: "Yang menjadi sasaran dalam pemasaran produk motor, kami memasang target akun-akun perusahaan dan memberikan penawaran dengan harga yang menarik perhatian", dari pertanyaa "Apa yang menjadi sasaran dalam pemasaran produk motor tersebut?"

Informan 3 (MW) menjawab; "Perusahaan-perusahaan menjadi sasaran dalam memasarakn produk motor kami dengan memberikan brosur dan embel-embel diskon juga khalayak luas yang dimana produk kami diiklankan di media sosial", dari pertaanyaan "Apa yang menjadi sasaran dalam pemasaran produk motor tersebut?".

Dalam penelitian Sulandjari dan Ardi (2020:36) menyatakan promosi dalam segala hal aktivitas apa spun yang dilakukan bertujuan untuk memajukan kepercayaan terhadap perusahaan dengan adanya promosi yang benar penerapannya dapat menumbuhkan loyalitas pelanggan pada perusahaan.

Public relation adalah stategi perusahaan untuk membangun hubungan baik dengan public supaya dapat mendapatkan opini yang baik dari kalangan masyarakat di sekitarnya Peran public relation dalam suatu bisnis yaitu berperan untuk perusahaan, juga merupakan konseling atau rekomendasi yang dapat memberikan berbagai saran, dan mengarahkan kepada pihak manajemen yang berhubungan dengan berbagai kebijakan, relasi, serta komunikasi antara perusahaan dengan publik. Setiap perusahaan yang bergerak dalam penjualan dan jasa, baik pemerintahataupun swasta, sangat memerlukan Public Relations untuk meningkatkan perusahaannya. Public Relations adalah suatu bentuk komunikasi yang berlaku untuk semua jenis 
organisasi baik yang bersifat komersial maupun non komersial disektor pemerintah maupun swasta. Peran Public Relations juga mencakup sebagai sebuah tim riset perilaku publik, karena public relations merupakan salah satu bagian perusahaan yang bersinggungan langsung dengan masyarakat umum.

Komunikasi yang berhubungan dengan masyarakat memiliki cakupan yang luas karena melakukan komunikasi dengan beberapa kelompok masyarakat guna menciptakan lingkungan yang kondusif untuk melakukan aktivitas pemasaran maupun kegiatan lainnya. Karena perusahaan adalah bisnis yang bisa terancam karena memiliki citra yang buruk. Maka dari itu public relation juga dapat mengambil peran sebagai manajemen karena membantu membangun dan memelihara komunikasi baik internal maupun eksternal. Dan juga harus tanggap terhadap opini opini publik guna mencegah isu negatif yang bisa merusak citra perusahaan. Seorang public relation juga harus memiliki skill Public affairs yaitu bagaimana membangun keterlibatan atau melakukan lobyying dengan pemerintah dalam membangun berbagai kebijakan publik. Dan juga agar produk yang di tawarkan beredar di pasaran dengan harapan mencapai target perusahaan diterima dengan baik di pasaran. Seorang public relation juga bisa dijadikan alat untuk memasarkan produknya karena merupakan bagian internal dalam suatu perusahaan. Karena Promosi merupakan salah satu strategi yang digunakan perusahaan untuk berkomunikasi dengan pasar, dengan harapan permintaan produk tersebut meningkat.

Seperti yang di lakukan oleh para pelaku public relation di perusahaan yamaha yang berada di cibiru kebanyakan dari mereka menggunakan strategi pemasaran dengan media sosial baik media sosial facebook, instagram dan lain lain. Dari informan yang kami dapatkan menggunakan media sosial untuk saat ini sangatlah efektif di karenakan pandemi yang semakin bertambah pengguna nya setiap waktunya. Hal ini sangatlah penting mengingat promosi adalh hal yang sangat penting untuk memajukan produk yang di hasilkan oleh perusahaan dalam cakupan ini adalah Yamaha dengan adanya promosi yang baik penerapannya dapat menumbuhkan loyalitas pelanggan pada perusahaan.

\section{KESIMPULAN}

Public relation adalah stategi perusahaan untuk membangun hubungan baik dengan public supaya dapat mendapatkan opini yang baik dari kalangan masyarakat di sekitarnya Peran public relation dalam suatu bisnis yaitu berperan untuk perusahaan, juga merupakan konseling atau rekomendasi yang dapat memberikan berbagai saran, dan mengarahkan kepada pihak manajemen yang berhubungan dengan berbagai kebijakan, relasi, serta komunikasi antara perusahaan dengan publik. Setiap perusahaan yang bergerak dalam penjualan dan jasa, baik pemerintahataupun swasta, sangat memerlukan Public Relations untuk meningkatkan perusahaannya. Karena perusahaan adalah bisnis yang bisa terancam karena memiliki citra yang buruk. Maka dari itu public relation juga dapat mengambil peran sebagai manajemen karena membantu membangun dan memelihara komunikasi baik internal maupun eksternal. Dan juga harus tanggap terhadap opini opini publik guna mencegah isu negatif yang bisa merusak citra perusahaan. Seorang public relation juga harus memiliki skill Public affairs yaitu bagaimana membangun keterlibatan atau melakukan lobyying dengan pemerintah dalam membangun berbagai kebijakan publik. Karena Promosi merupakan salah satu strategi yang digunakan perusahaan untuk berkomunikasi dengan pasar, dengan harapan permintaan produk tersebut meningkat. Seperti yang di lakukan oleh para pelaku public relation di perusahaan yamaha yang berada di cibiru kebanyakan dari mereka menggunakan strategi pemasaran dengan media sosial baik media sosial facebook, instagram dan lain lain.

\section{Referensi}

Cangara Hafied, (2011). Pengantar Ilmu Komunikasi, Jakarta: PT.Rajagrafindo, 12(1). 18-19.

Muchlisin Riadi,( 2018). Pengertian, Bauran dan Strategi Komunikasi Pemasaran. Diaksespada tanggal 28 januari 2021 https://www.kajianpustaka.com/2018/11/pengertian-bauran-dan-strategi-komunikasipemasaran.html

Widoyoko. (2015). Teknik penyusuna instrument penelitian. Yogyakarta: Pustaka pelajar.

Sudijono, A (2011). Pengantar evaluasi pendidikan. Jakarta: PT. Raja Grafindo Persada

Ishak, A. (2012). Peran publik relation dalam komunikasi organisasi. Jurnal komunikasi, 1(4): 375-376. 
Dharnayanti, N.M.P. (2017) Hubungan hukum perusahaan induk berbentuk perseroan terbatas dengan anak perusahaan berbentuk persekutuan, commanditer. Jurnal ilmiah prodi magister kenotaritan. 1(1): 67 68.

Nasution, IA. (2019) Peraan public relation dalam meningkatkan pelayanan informs hotel garuda plaza. Jurnal warta edisi 61: 139-140.

Artis. (2011) Strategi komunikasi public relation. Jurnal sosial budaya. 8(2): 186-187.

Primani, Armie (2015) REPOSISI PERAN DAN FUNGSI STRATEGIS PUBLIC RELATIONS DALAM ORGANISASI PENDIDIKAN. Jurnal Lentera Komunikasi, 1(1).

Isna Asdiani Nasution (2019) PERANAN PUBLIC RELATIONS DALAM MENINGKATKAN PELAYANAN INFORMASI HOTEL GARUDA PLAZA. Jurnal warta Edisi.

Purbohastuti, WA. (2017). EFEKTIVITAS MEDIA SOSIAL SEBAGAI MEDIA PROMOSI. Tirtayasa EKONOMIKA. Vol. 12, (2) : 230-231

Rahayu, DWS. (2019). Penerapan Diskon Dalam Menarik Minat Beli Konsumen Di Matahari Departement Store Kediri Town Square. Akuntabilitas: Jurnal IImu-IImu Ekonomi. Vol 12 (2): 50-51

Sulandjari, R., Dan Ardi, F. (2020). PENGARUH PROMOSI TERHADAP LOYALITAS PELANGGAN DI ONLINE SHOP BRILINK_KHUMAIRA. Jurnal Egaliter, Vol 4 (7) : 36-37.

Untari, D., dan Dewi, DE. (2018). Strategi Pemasaran Melalui Media Sosial Instagram (Studi Deskriptif Pada Akun@Subur_Batik).Widya Cipta : Jurnal Sekretari Dan Manajemen.Vol.2 (2 ):273-274 